\title{
PENGARUH TEKNIK INJEKSI STEROID DENGAN TUNTUNAN ULTRASONOGRAFI TERHADAP LUARAN KLINIS PASIEN CARPAL TUNNEL SYNDROME
}

\author{
EFFECT OF STEROID INJECTION TECHNIQUE WITH ULTRASOUND \\ GUIDANCE ON CLINICAL OUTCOMES IN CARPAL TUNNEL SYNDROME PATIENTS
}

Mariana Sutopo, * Yudy Goysal, * David Gunawan Umbas, * Susi Aulina, Louis Kwandou, * Andi Alfian Zainuddin*

\section{ABSTRACT}

Introduction: Carpal tunnel syndrome (CTS) is the most common entrapment neuropathy in the upper extremity and one of the diseases that causes disability, thereby reducing productivity. This study purpose is to determine the effect of steroid injection techniques with and without ultrasound guidance on clinical outcomes in patients with CTS.

Method: This study was a clinical trial with a non-randomized pretest-posttest-control group design. This study subjects were 36 patients with CTS, consisting of 18 wrists receiving steroid injection with ultrasound guidance and 18 wrists without ultrasound guidance.

Results: The results showed a significant change in the Symptom Severity Scale (SSS) and Functional Status Scale (FSS) $(p<0.05)$ after treatment in the steroid injection group with and without ultrasound guidance. The results of the unpaired t-test on changes in the SSS between the groups who received steroid injection with ultrasound guidance and without ultrasound guidance showed no significant difference $(p>0.05)$. The results of the Mann-Whitney test on changes in FSS scores between groups who received steroid injections with and without ultrasound guidance showed no significant differences $(p>0.05)$.

Discussion: Decrease in Boston SSS and FSS after steroid injections in both groups were in accordance with theory that steroid injection can quickly bind directly to nerve cell receptors and inhibit production of proinflammatory mediators. Whereas results of the study comparing effectiveness of steroid injection techniques with ultrasound guidance and without ultrasound guidance were not significant because observations were only made for 1 week.

Keywords: Carpal tunnel syndrome, functional status scale, steroid injection, symptom severity scale, USG-guided

\section{ABSTRAK}

Pendahuluan: Carpal tunnel syndrome (CTS) adalah neuropati jebakan yang paling sering pada ekstremitas atas dan merupakan salah satu penyakit yang menyebabkan disabilitas, sehingga menurunkan produktivitas. Penelitian ini bertujuan mengetahui pengaruh teknik injeksi steroid dengan dan tanpa tuntunan ultrasonografi terhadap luaran klinis pada pasien carpal tunnel syndrome.

Metode: Penelitian ini adalah uji klinis dengan rancangan non-randomized pretest-posttest-control-group. Penelitian ini dilakukan terhadap 36 pasien CTS, terdiri dari 18 pergelangan tangan yang mendapat injeksi steroid dengan tuntunan USG dan 18 pergelangan tangan tanpa tuntunan USG.

Hasil: Hasil penelitian menunjukkan adanya perubahan Symptom Severity Scale (SSS) dan Functional Status Scale (FSS) yang bermakna $(\mathrm{p}<0,05)$ setelah perlakuan pada kelompok injeksi steroid dengan dan tanpa tuntunan USG. Hasil uji-t tidak berpasangan terhadap perubahan SSS antara kelompok yang mendapat injeksi steroid dengan tuntunan USG dan tanpa tuntunan USG menunjukkan perbedaan tidak bermakna ( $p>0,05)$. Hasil uji Mann-Whitney terhadap perubahan skor FSS antara kelompok yang mendapat injeksi steroid dengan tuntunan USG dan tanpa tuntunan USG menunjukkan perbedaan tidak bermakna ( $\mathrm{p}>0,05)$.

Diskusi: Penurunan SSS dan FSS kuesioner Boston setelah dilakukan injeksi steroid pada kedua kelompok ini sesuai dengan teori bahwa injeksi steroid dapat dengan cepat berikatan langsung dengan reseptor sel saraf. Ikatan steroid dengan reseptor di sel saraf dapat menghambat produksi mediator proinflamasi. Sedangkan hasil penelitian yang membandingkan efektivitas teknik injeksi steroid dengan tuntunan USG dan tanpa tuntunan USG tidak bermakna karena pengamatan hanya dilakukan selama 1 minggu.

Kata kunci: Carpal tunnel syndrome, functional status scale, injeksi steroid, symptom severity scale, USG-guided

*Departemen/SMF Neurologi, Universitas Hasanuddin/RSUP Wahidin Sudirohusodo, Makassar. Korespondensi: sutopo.mariana@ gmail.com.

\section{PENDAHULUAN}

Carpal tunnel syndrome (CTS) adalah neuropati jebakan yang paling sering pada ekstremitas atas dan merupakan salah satu penyakit yang menyebabkan

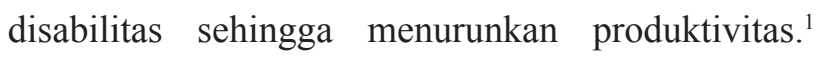
Perempuan lebih rentan terhadap CTS dibanding 
laki-laki dengan rasio 3:1 hingga 10:1. CTS pada umumnya bilateral dengan rentang usia puncak 40-60 tahun. Prevalensi CTS di Amerika Serikat adalah $5-21 \%$ pada pekerja pabrik dan $1-5 \%$ pada populasi umum. Berdasarkan data dari Washington State Workers, insiden CTS adalah 0,8-14,8 per 1000 orang per tahun. ${ }^{2}$

Penyebab terjadinya CTS adalah peningkatan tekanan di terowongan karpal. Pada orang normal tekanan di terowongan karpal sebesar $2 \mathrm{mmHg}$. Tekanan tersebut akan meningkat saat fleksi dan ekstensi pergelangan tangan. Tekanan sebesar 20-30mmHg dapat memperlambat aliran darah epineurium saraf. Transpor aksonal terganggu pada tekanan 30mmHg. Perubahan neurofisiologis berupa disfungsi motorik dan sensorik akan muncul pada tekanan 40mmHg. Sedangkan pada tekanan 60$80 \mathrm{mmHg}$ terjadi penghentian aliran darah intraneural yang menyebabkan iskemia sehingga terjadi kerusakan sel saraf. Walaupun lesi saraf perifer lebih resisten terhadap iskemia, namun tegangan dan kompresi yang berkepanjangan dapat menyebabkan terjadinya proses iskemia tersebut. ${ }^{3}$ Dari beberapa penelitian didapatkan pula bahwa pada penderita CTS terdapat perubahan berupa peningkatan prostaglandin, VEGF dan TNF- $\alpha$. Pelepasan mediator proinflamasi tersebut menyebabkan terjadinya peningkatan permeabilitas vaskular dan menimbulkan edema lokal. ${ }^{4}$

Injeksi steroid dapat mengurangi efek inflamasi yang terjadi pada CTS melalui penghambatan produksi sitokin proinflamasi. Selain itu, dalam beberapa tahun terakhir dilakukan analisis efek steroid pada dua protein yang paling khas dan penting dari mielin sistem saraf perifer (PNS), glikoprotein Po (po) dan peripheral myelin protein 22 (PMP22 -protein mielin perifer 22). Hasil yang diperoleh sejauh ini menunjukkan bahwa hormon steroid mampu memodulasi mRNA protein mielin sehingga dapat memperbaiki mielin saraf perifer yang mengalami kerusakan. ${ }^{5-6}$

Dalam praktek klinis sehari-hari injeksi steroid umumnya dilakukan tanpa tuntunan USG dengan cara palpasi area anatomi nervus medianus. Teknik ini tidak dapat mengetahui apakah steroid yang diinjeksikan benar masuk di terowongan karpal. Sebuah studi kadaver telah menunjukkan bahwa terdapat variabilitas luas dari distribusi injeksi. Selain itu, injeksi steroid cenderung menyebabkan komplikasi seperti kerusakan saraf, kerusakan pembuluh darah, dan lesi kulit (misalnya perubahan warna). Lesi nervus medianus adalah komplikasi paling serius yang terkait dengan injeksi steroid lokal untuk CTS tanpa tuntunan USG. Oleh karena itu, injeksi di bawah tuntunan USG dapat meningkatkan ketepatan dan hasil terapi serta menurunkan tingkat komplikasi. Hanya ada beberapa penelitian yang telah menyelidiki pedoman tata laksana suntikan untuk CTS di Amerika Serikat. Umumnya mereka menetapkan bahwa injeksi dengan tuntunan USG memberikan perbaikan gejala klinis dan efek terapi yang meningkat dan bertahan lama dibandingkan dengan injeksi steroid tanpa tuntunan USG. ${ }^{7}$

Untuk mengevaluasi gejala klinis dan tingkat keparahan fungsional pada pasien dengan CTS dapat digunakan kuesioner Boston yang terdiri dari 2 unsur penilaian, yaitu: Symptom Severity Scale (SSS) dan Functional Status Scale (FSS). Skor SSS merupakan penilaian berdasarkan tingkat keparahan, frekuensi, dan lama penyakit, sedangkan FSS digunakan untuk menilai pengaruh gejala klinis yang ada terhadap aktivitas sehari-hari. ${ }^{8}$

\section{TUJUAN}

Mengetahui pengaruh teknik injeksi steroid dengan dan tanpa tuntunan USG terhadap luaran klinis menggunakan kuesioner Boston pada pasien CTS.

\section{METODE}

Desain penelitian ini adalah uji klinis dengan rancangan non-randomized pretest-posttest-control group. Penelitian dilakukan di RSUP dr. Wahidin Sudirohusodo Makassar mulai bulan Mei 2018 sampai jumlah sampel mencukupi. Populasi penelitian adalah semua pasien CTS di RSUP dr. Wahidin Sudirohusodo. Sampel penelitian adalah seluruh populasi terjangkau yang memenuhi kriteria penelitian. Sampel penelitian diperoleh berdasarkan urutan masuknya di RS (consecutive sampling). 
Pasien yang datang pertama kali dimasukkan ke dalam kelompok injeksi steroid dengan tuntunan USG dan pasien yang datang selanjutnya dimasukkan ke dalam kelompok injeksi steroid tanpa tuntunan USG, dan bergantian seterusnya sampai sampel kedua kelompok terpenuhi. Alat dan bahan meliputi lembaran persetujuan peserta/keluarga untuk ikut penelitian, lembaran informed consent untuk peserta penelitian/keluarga, alat-alat pemeriksaan neurologi, seperti palu refleks, jarum pentul, kapas, USG (merek GE made in China), lembaran formulir penelitian (kuesioner Boston), triamsinolon asetonid $10 \mathrm{mg} / \mathrm{mL}$, spuit $3 \mathrm{~mL}$ merek Terumo, jarum nomor 26 merek Terumo. Penegakkan diagnosis CTS berdasarkan hasil pemeriksaan Elektro Neuro Miogragi (ENMG) dengan menggunalan alat Cadwell Sierra Summit 12Ch. Amplifier Made in USA.

Kriteria inklusi dalam penelitian ini, yaitu: (1) semua penderita CTS yang terdiagnosis berdasarkan pemeriksaan latensi distal motorik dan sensorik yang diperoleh dari elektroneuromiografi, (2) usia 40-60 tahun, dan (3) menyatakan tidak keberatan disertakan dalam penelitian dengan menandatangani surat persetujuan oleh pasien atau wali pasien. Sedangkan kriteria eksklusi, yaitu: (1) pernah mendapat injeksi steroid lokal sebelumnya dalam 3 bulan terakhir, (2) atrofi otot tenar, (3) latensi distal motorik $\geq 6,5$ milidetik. Kriteria pengunduran diri, yaitu: (1) pasien mengundurkan diri atau tidak bersedia melanjutkan penelitian, (2) pasien meninggal dunia.

Pengisian kuesioner Boston oleh sampel sebelum dan tujuh hari setelah tindakan. Kuesioner Boston terdiri dari 2 bagian pertanyaan, yaitu bagian SSS yang terdiri dari 11 pertanyaan dan FSS yang terdiri dari 8 pertanyaan. Masing-masing pertanyaan bernilai minimal 1 dan maksimal 5. Pengisian kuesioner Boston dilakukan sendiri oleh pasien dengan arahan peneliti.

Injeksi steroid lokal dengan dan tanpa tuntunan USG dilakukan dengan cara sebagai berikut: (1) injeksi steroid lokal dengan tuntunan USG adalah prosedur memasukkan obat steroid berupa triamsinolon asetonid $10 \mathrm{mg}$ secara injeksi menggunakan jarum nomor 26 dengan sudut $45^{\circ}$ dengan cara terlebih dahulu meletakkan probe USG pada pergelangan tangan yang akan dilakukan injeksi steroid. Posisi pasien duduk dengan siku fleksi $90^{\circ}$ dan tangan diletakkan di atas meja. Lokasi yang akan diinjeksi steroid dibersihkan terlebih dahulu cairan antiseptik. Kemudian jarum mulai dimasukkan dari sisi ulnar transducer sambil peneliti tetap mengamati nervus medianus. Teknik ini dilakukan untuk CTS unilateral maupun bilateral; (2) injeksi steroid lokal tanpa tuntunan USG yaitu prosedur memasukkan obat steroid berupa triamsinolon asetonid $10 \mathrm{mg}$ secara injeksi blind menggunakan jarum nomor 26 dengan sudut $45^{\circ}$, berdasarkan keterampilan dan pengalaman peneliti. Posisi pasien dalam keadaan duduk dengan siku fleksi $90^{\circ}$ dan tangan diletakkan di atas meja. Lokasi yang akan diinjeksi steroid dibersihkan terlebih dahulu dengan cairan antiseptik. Jarum mulai dimasukkan dari sisi ulnar ke dalam terowongan karpal proksimal di bagian distal lipatan pergelangan tangan. Ketika jarum melewati terowongan karpal, pasien diminta menggerakkan jarinya. Jika tendon fleksor tertusuk, maka jarum bergerak dan terasa nyeri. Jarum kemudian ditarik hingga jari bisa digerakkan. Teknik ini dilakukan untuk CTS unilateral maupun bilateral.

Pasien diamati pada saat pertama kali mendapat injeksi triamsinolon dan 1 minggu kemudian menggunakan kuesioner Boston. Data yang diperoleh dari dua pengamatan tersebut, dicatat dan dikelompokkan berdasarkan jenis data dan tujuan penelitian, yaitu mengetahui pengaruh teknik injeksi steroid dengan dan tanpa tuntunan USG terhadap luaran klinis menggunakan kuesioner Boston pada pasien CTS. Kemudian dipilih metode statistik yang sesuai, yaitu dilakukan analisis komparasi dengan menggunakan uji $\mathrm{t}$ berpasangan dan uji $\mathrm{t}$ tidak berpasangan jika distribusi sampel normal, uji MannWhitney dan uji Wilcoxon jika distribusi sampel tidak normal, dengan batas kemaknaan $\mathrm{p}<0,05$ menggunakan SPSS 21.0.

\section{HASIL}

Penelitian ini dilakukan di rumah sakit pendidikan di Makassar, yaitu RSUP dr. Wahidin Sudirohusodo pada periode Mei sampai dengan 
Tabel 1. Karakteristik Sampel $(n=36)$

\begin{tabular}{lccc}
\hline $\begin{array}{c}\text { Karakteristik } \\
\text { n (\%) }\end{array}$ & $\begin{array}{c}\text { Injeksi } \\
\text { Steroid } \\
\text { dengan USG } \\
(\mathbf{n = 1 8 )}\end{array}$ & $\begin{array}{c}\text { Injeksi Steroid } \\
\text { tanpa Tuntunan } \\
\text { USG (n=18) }\end{array}$ & $\mathbf{p}$ \\
\hline Jenis kelamin & & & \\
- Perempuan & $17(94,4)$ & $14(77,8)$ & 0,148 \\
- Laki-laki & $1(5,6)$ & $4(22,2)$ & \\
Lokasi CTS & & & \\
- Kanan & $10(55,6)$ & $11(61,1)$ & 0,735 \\
- Kiri & $8(44,4)$ & $7(38,9)$ & \\
Derajat CTS & & & \\
- Berat & $7(38,9)$ & $3(16,7)$ & \\
- Sedang & $10(55,6)$ & $15(83,3)$ & \\
- Ringan & $1(5,6)$ & 0 & \\
Pekerjaan & & & \\
- IRT & $6(33,3)$ & $8(44,4)$ & \\
- Wiraswasta & $2(11,1)$ & $5(27,8)$ & \\
- PNS & $5(27,8)$ & $5(27,8)$ & \\
- Guru & $3(16,7)$ & 0 & \\
- Swasta & $2(11,1)$ & 0 & \\
\hline
\end{tabular}

USG: Ultrasonografi.

September 2018. Sampel penelitian diperoleh secara consecutive sampling yaitu pasien CTS yang memenuhi kriteria inklusi. Pada penelitian ini terkumpul 36 pasien CTS yang terdiri dari 31 perempuan dan 5 laki-laki. Data dasar karakteristik sampel pada 2 kelompok dapat dilihat pada tabel 1 dan tabel 2.

Pada tabel 2 dapat dilihat bahwa tidak ada perbedaan karakteristik sampel (jenis kelamin, umur, tinggi badan, berat badan, dan BMI) yang bermakna antara kedua kelompok perlakuan.

Hasil penelitian ini menunjukkan adanya perubahan skor SSS yang bermakna setelah perlakuan, baik pada kelompok injeksi steroid dengan tuntunan USG maupun kelompok injeksi steroid tanpa tuntunan USG (Tabel 3). Tidak ada perbedaan rerata skor SSS antara kelompok yang mendapat injeksi steroid dengan tuntunan USG dan tanpa tuntunan USG (Tabel 4).

Hasil penelitian ini juga menunjukkan adanya perubahan skor FSS yang bermakna setelah perlakuan, baik pada kelompok injeksi steroid dengan tuntunan USG maupun kelompok injeksi steroid tanpa tuntunan USG (Tabel 3). Tidak ada perbedaan rerata skor FSS bermakna antara kelompok yang mendapat injeksi steroid dengan tuntunan USG dan tanpa tuntunan USG.

Tabel 2. Analisis Karakteristik Sampel $(n=36)$

\begin{tabular}{|c|c|c|c|}
\hline \multirow[b]{2}{*}{ Variabel } & \multicolumn{2}{|c|}{ Kelompok } & \multirow[b]{2}{*}{$\mathbf{p}$} \\
\hline & $\begin{array}{c}\text { USG }(n=18) \\
(\operatorname{Rerata} \pm \text { SD) }\end{array}$ & $\begin{array}{c}\operatorname{Blind}(\mathrm{n}=18) \\
(\operatorname{Rerata} \pm \mathrm{SD})\end{array}$ & \\
\hline Jenis Kelamin & $\mathrm{n}=18$ & $\mathrm{n}=18$ & \\
\hline - Laki-laki & 1 & 4 & $0,15^{*}$ \\
\hline - Perempuan & 17 & 14 & \\
\hline Usia (tahun) & $51,1 \pm 5,9$ & $52,3 \pm 7,4$ & $0,64 * *$ \\
\hline Tinggi badan $(\mathrm{cm})$ & $157,5 \pm 6,2$ & $161,9 \pm 6,3$ & $0,05 * *$ \\
\hline Berat badan $(\mathrm{kg})$ & $61,8 \pm 7,7$ & $65,5 \pm 7,5$ & $0,24 * *$ \\
\hline $\operatorname{IMT}\left(\mathrm{kg} / \mathrm{m}^{2}\right)$ & $25,00+3,2$ & $25,06 \pm 3,4$ & $0,75 * *$ \\
\hline
\end{tabular}

*Chi-square test; **Mann-Whitney test.USG: ultrasonografi; IMT: indeks massa tubuh; SD: standar deviasi.

Tabel 3. Perubahan Symptom Severity Scale dan Functional Status Scale pada Kedua Kelompok (n=36)

\begin{tabular}{|c|c|c|c|c|c|c|}
\hline \multirow[t]{2}{*}{ Kelompok } & \multicolumn{2}{|c|}{$\begin{array}{c}\text { Rerata } \pm \text { SD } \\
\text { Symptom Severity Scale }\end{array}$} & \multirow{2}{*}{$\mathbf{p}$} & \multicolumn{2}{|c|}{$\begin{array}{c}\text { Rerata } \pm \text { SD } \\
\text { Functional Status Scale }\end{array}$} & \multirow[b]{2}{*}{$\mathbf{p}$} \\
\hline & Sebelum & Sesudah & & Sebelum & Sesudah & \\
\hline USG $(n=18)$ & $2,7 \pm 0,8$ & $1,6 \pm 0,4$ & $<0,001 *$ & $1,9 \pm 0,9$ & $1,3 \pm 0,4$ & $0,001 * *$ \\
\hline Blind $(\mathrm{n}=18)$ & $2,9 \pm 0,9$ & $1,8 \pm 0,8$ & $<0,001 * *$ & $2,6 \pm 1,3$ & $1,6 \pm 0,8$ & $0,001 * *$ \\
\hline
\end{tabular}


Artikel Penelitian

Tabel 4. Analisis Perubahan Symptom Severity Scale dan Functional Status Scale pada Kedua Kelompok (n=36)

\begin{tabular}{lccccc}
\hline \multirow{2}{*}{ Kelompok } & \multicolumn{3}{c}{ Symptom Severity Scale } & \multicolumn{2}{c}{ Functional Status Scale } \\
\cline { 2 - 6 } & Rerata \pm SD & \multirow{2}{*}{$*$} & $\begin{array}{c}\text { Perbedaan Rerata } \\
\text { (IK 95\%) }\end{array}$ & $\begin{array}{c}\text { Median } \\
\text { (Min-Maks) }\end{array}$ & $\mathbf{p}^{*}$ \\
\hline USG $(\mathrm{n}=18)$ & $1,0 \pm 0,7$ & $\mathrm{p}=0,627$ & $-0,10(-0,51-0,31)$ & $0,3(0,0-2,0)$ & 0,323 \\
Blind $(\mathrm{n}=18)$ & $1,1 \pm 0,7$ & & & $0,5(0,0-3,5)$ & \\
\hline
\end{tabular}

SD: standar deviasi; IK: interval kepercayaan; min-maks: minimum-maksimum.

\section{PEMBAHASAN}

Hasil penelitian ini menunjukkan adanya perubahan skor SSS dan FSS yang bermakna setelah perlakuan, baik pada kelompok injeksi steoid dengan tuntunan USG maupun kelompok injeksi steroid tanpa tuntunan USG (Tabel 3). Kesimpulannya, injeksi steroid dapat memperbaiki gejala CTS serta fungsionalnya sesuai dengan penelitian sebelumnya.

Penurunan skor kuesioner Boston baik pada komponen SSS maupun FSS setelah dilakukan injeksi steroid ini sesuai dengan teori bahwa injeksi steroid lebih unggul dibandingkan pemberian steroid secara oral. ${ }^{9}$ Hal ini disebabkan steroid berikatan secara langsung dengan reseptor sel saraf. Ikatan steroid dengan reseptor di sel saraf dapat menghambat produksi mediator proinflamasi, yang selanjutnya menghambat proses inflamasi. ${ }^{10}$ Selain itu, sesuai dengan penelitian lain yang melakukan analisis terhadap efek steroid pada dua protein yang paling khas dan penting dari mielin sistem saraf perifer (PNS), yaitu glikoprotein Po (po) dan protein mielin perifer 22 (PMP22), menunjukkan bahwa hormon steroid mampu memodulasi mRNA protein mielin sehingga dapat memperbaiki mielin saraf perifer yang mengalami kerusakan. ${ }^{5-6}$

Review Cochrane menunjukkan injeksi steroid lokal dapat mengurangi gejala CTS hingga 1 bulan setelah injeksi, sedangkan pada penelitian lain disebutkan bahwa injeksi steroid masih menunjukkan efeknya 3 bulan sampai 1 tahun. Injeksi steroid juga dapat menunda tindakan pembedahan pada pasien CTS menurut penelitan yang dilakukan. ${ }^{11-12}$ Sebuah penelitian menunjukkan efek injeksi steroid mulai terlihat dalam waktu satu minggu setelah injeksi, sedangkan penelitian lain menyebutkan injeksi steroid baru menujukkan efek setelah satu bulan. ${ }^{11}$ Demikian juga dengan penelitian terhadap 69 pasien
CTS yang membagi pasien menjadi dua kelompok, yaitu injeksi steroid (triamsinolon asetonid $10 \mathrm{mg}$ ) dan normal saline. Penelitian tersebut menunjukkan adanya perbaikan klinis pada kelompok yang diinjeksi steroid setelah 1 minggu. Perbaikan ini menetap setelah pengamatan selama 10 minggu. ${ }^{13}$ Oleh karena itu, pada penelitian ini dilakukan pengamatan selama 1 minggu untuk menilai efektivitas pemberian injeksi steroid.

Dalam penelitian ini, selain menilai efektivitas pemberian injeksi steroid dengan menggunakan kuesioner Boston, penulis juga menilai perbedaan teknik injeksi steroid dengan menggunakan tuntunan USG dan tanpa tuntunan USG. Pada penelitian ini didapatkan perubahan skor SSS masing-masing kelompok sebesar 1,0 dan 1,1. Hasil uji t tidak berpasangan terhadap perubahan skor SSS antara kelompok yang mendapat injeksi steroid dengan tuntunan USG dan tanpa tuntunan USG (blind) menunjukkan tidak terdapat perbedaan bermakna. Sedangkan perubahan skor FSS masing-masing kelompok sebesar 0,3 dan 0,5. Hasil uji MannWhitney terhadap perubahan skor FSS antara kelompok yang mendapat injeksi steroid dengan tuntunan USG dan tanpa tuntunan USG menunjukkan tidak terdapat perbedaan bermakna.

Hasil penelitian ini, pada pengamatan 1 minggu, tidak sesuai dengan teori penelitian sebelumnya yang menyatakan bahwa injeksi steroid dengan tuntunan USG lebih efektif dalam penurunan gejala dan perbaikan fungsi pada pasien CTS dengan risiko lebih rendah terhadap lesi nervus dibandingkan injeksi steroid lokal tanpa tuntunan USG. ${ }^{13}$ Penelitian lain menyebutkan bahwa injeksi steroid lokal dengan tuntunan USG dan tanpa tuntunan USG sama-sama memiliki efektivitas dalam menurunkan gejala dan memperbaiki fungsi pergelangan tangan yang mengalami CTS. Namun, injeksi steroid dengan 
tuntunan USG lebih efektif memberikan perbaikan klinis secara singkat dibandingkan tanpa tuntunan USG dalam tata laksana pasien dengan CTS berat. ${ }^{7}$ Penelitian lain yang pernah dilakukan juga menyatakan bahwa pemberian injeksi steroid lokal menggunakan tuntunan USG dengan cara pendekatan ulnaris secara in-plane lebih efektif dibandingkan secara out-plane dan tanpa tuntunan USG. Hal ini disebabkan injeksi dengan tuntunan USG dapat meningkatkan ketepatan dan hasil terapi serta menurunkan tingkat komplikasi. Keunggulan lain injeksi dengan tuntunan USG adalah efek terapi yang meningkat dan lebih bertahan lama dibandingkan tanpa tuntunan USG. ${ }^{15}$ Penelitian pada kadaver menyatakan bahwa terdapat variabilitas luas dari distribusi injeksi steroid tanpa tuntunan USG. Kesalahan lokasi injeksi atau injeksi yang tidak dapat terdistribusi secara bebas di dalam terowongan karpal kemungkinan akan menghasilkan gejala sisa atau kekambuhan gejala lebih dini. ${ }^{7}$

Efektivitas yang lebih tinggi pada kelompok yang mendapat injeksi steroid dengan tuntunan USG tergantung pada pengalaman dokter sebagai operator sehingga tidak dapat dikesampingkan bahwa dokter operator dapat menjadi perancu. Operator untuk injeksi steroid dengan tuntunan USG dan tanpa tuntunan USG pada penelitian ini dilakukan oleh orang yang sama. Namun, operator lebih sering melakukan injeksi steroid tanpa tuntunan USG pada pasien CTS dibanding menggunakan tuntunan USG. Hal ini diduga menyebabkan penurunan skor kuesioner Boston yang lebih besar pada kelompok yang mendapat injeksi steroid tanpa tuntunan USG dibandingkan dengan tuntunan USG. Faktor keahlian dan pengalaman dokter yang menjadi operator menentukan hasil dari penelitian ini.

Keterbatasan penelitian ini adalah tidak membedakan penyakit lain yang mungkin berperan terhadap terjadinya CTS seperti diabetes melitus, rheumatoid arthritis, trauma mekanik, tiroid, kehamilan, dan lain-lain. Penelitian ini juga tidak melihat perbedaan derajat CTS terhadap respons terapi dengan kedua teknik injeksi. Waktu pengamatan dilakukan secara singkat selama 1 minggu tanpa pengamatan lanjutan.

\section{KESIMPULAN}

Injeksi steroid pada CTS menunjukkan perbaikan keluhan/fungsional terapi baik dengan atau tanpa tuntunan USG pada 1 minggu pengamatan.

\section{DAFTAR PUSTAKA}

1. Yunoki M, Kanda T, Suzuki K, Uneda A, Hirashita K, Yoshino K. Importance of recognizing carpal tunnel syndrome for neuzrosurgeons: A review. Neurol Med Chir. 2017;57(4):172-82.

2. Dale AM, Harris-Adamson C, Rempel D, Gerr F, Hegmann K, Silverstein B, dkk. Prevalence and incidence of carpal tunnel syndrome in US working populations: Pooled analysis of six prospective studies. Scand J Work Environ Health. 2013;39(5):495-505.

3. Aboonq MS. Pathophysiology of carpal tunnel syndrome. Neurosciences. 2015;20(1):4-9.

4. Sardana V, Ojha P. Carpal tunnel syndrome: Current review. Int J Med Res Prof. 2016;2(1):8-14.

5. Watila MM, Balarabe SA. Molecular and clinical features of inherited neuropathies due to PMP22 duplication. J Neurol Sci. 2015;355(1-2):18-24.

6. Li J, Parker B, Martyn C, Natarajan C, Guo J. The PMP22 gene and its related diseases. Mol Neurobiol. 2013;47(2):673-98.

7. Karaahmet OZ, Gurcay E, Kara M, Serce A, Kurac Unal Z, Cakci A. Comparing the effectiveness of ultrasound-guided versus blind steroid injection in the treatment of severe carpal tunnel syndrome. Turk J Med Sci. 2017;47(6):1785-90.

8. Erkol E, Eroglu P. Analysis of the relationships between electroneurography and Boston questionnaire in obese female patients with carpal tunnel syndrome. SDU Saglik Bilimleri Enstitusu Dergisi. 2015;6:726.

9. Shah S, Kim ED. Carpal tunnel steroid injection: Overview, indications, contraindications Medscape [serial online]. 2018 [diunduh 28 November 2018]. Tersedia dari: Medscape.

10. Straub RH, Cutolo M. Glucocorticoids and chronic inflammation. Rheumatology. 2016;55(Supl 2):ii614.

11. Hoffecker B, Aaron H, Jessica J, Douglas L, Jennifer W. Efficacy of local corticosteroid injection for carpal tunnel syndrome. Kansas Journal of Medicine. 2015:170-4.

12. Evers S, Bryan AJ, Sanders TL, Selles RW, Gelfman R, Amadio PC. Effectiveness of ultrasound-guided compared to blind steroid injections in the treatment of carpal tunnel syndrome. Arthritis Care Res. 2017;69(7):1060-5. 
13. InformedHealth.org. Carpal tunnel syndrome: How effective are corticosteroid treatments? InformedHealth [serial online]. Institute for Quality and Efficiency in Health Care (IQWiG). 2017 [diunduh 27 November 2018]. Tersedia dari: NCBI.

14. Dabees N, El-Saadany H, El-Barbary A, Ammar AS. Ultrasound guided steroids injection for carpal tunnel syndrome. Int J Med Imaging. 2015;3(4):75.

15. Lee JY, Park Y, Park KD, Lee JK, Lim OK. Effectiveness of ultrasound-guided carpal tunnel injection using in-plane ulnar approach. Medicine (Baltimore) [serial online]. 2014 [diunduh $5 \mathrm{Mei}$ 2018];93(29). Tersedia dari: NCBI. 